[Supporting Information to accompany J. Am. Chem. Soc. manuscript \# JA056378K-31-335]

\title{
Multifunctional Polymeric Nanoparticles from Diverse Bioactive Agents
}

\author{
Paul A. Bertin, ${ }^{\dagger}$ Julianne M. Gibbs, ${ }^{\dagger}$ Clifton Kwang-Fu Shen, ${ }^{\dagger}$ C. Shad Thaxton, ${ }^{\dagger}$ William A. Russin,,${ }^{\dagger}$ Chad A. Mirkin, ${ }^{\dagger}$ \\ and SonBinh T. Nguyen ${ }^{t * *}$ \\ ${ }^{\dagger}$ Department of Chemistry and International Institute for Nanotechnology, ${ }^{*}$ Biological Imaging Facility and Department of \\ Neurobiology and Physiology, Northwestern University, 2145 Sheridan Road, Evanston, Illinois, USA 60208-3113
}

Full citation for reference 9b in manuscript: Slamon, D. J.; Godolphin, W.; Jones, L. A.; Holt, J. A.; Wong, S. G.; Keith, D. E.; Levin, W. J.; Stuart, S. G.; Udove, J.; Ullrich, A.; Press, M. F. Science 1989, 244, 707-712.

\section{Materials and Methods:}

General considerations. All synthetic manipulations were performed under a dry nitrogen atmosphere using either standard Schlenk techniques or an inert-atmosphere glovebox, unless otherwise noted. For reaction media, HPLC-grade tetrahydrofuran (THF) and methylene chloride were dried over neutral alumina via the Dow-Grubbs solvent system ${ }^{1}$ installed by Glass Contours (Laguna Beach, CA). These solvents were collected under argon, degassed under vacuum, and stored under nitrogen in a Strauss flask prior to use. ${ }^{1} \mathrm{H}$ and ${ }^{13} \mathrm{C}$ NMR spectra were recorded on a Varian INOVA $500 \mathrm{FT}-$ NMR spectrometer (500 MHz for ${ }^{1} \mathrm{H}$ NMR, $125 \mathrm{MHz}$ for ${ }^{13} \mathrm{C}$ NMR). ${ }^{1} \mathrm{H}$ NMR data are reported as follows: chemical shift $\{$ multiplicity $(\mathrm{b}=$ broad, $\mathrm{s}=$ singlet, $\mathrm{d}=$ doublet, $\mathrm{t}=$ triplet, $\mathrm{q}=$ quartet, $\mathrm{qn}=$ quintet, and $\mathrm{m}=$ multiplet $)$, integration, and peak assignments $\}.{ }^{1} \mathrm{H}$ and ${ }^{13} \mathrm{C}$ chemical shifts are reported in ppm downfield from tetramethylsilane (TMS). Peak assignments were made with the assistance of ACD Labs software.

High-resolution electron-impact mass spectrometry (HREIMS) and atmospheric-pressure chemical ionization mass spectrometry (APCIMS) data were obtained on a VG70-250SE high-resolution mass spectrometer. Polymer molecular weights were measured relative to polystyrene standards on a Waters gel-permeation chromatograph (GPC) equipped with Breeze software, a 717 autosampler, Shodex KF-G guard column, KF-803L and KF-806L columns in series, a Waters 2440 UV detector, and a $410 \mathrm{RI}$ detector. HPLC-grade THF was used as the eluent at a flow rate of $1.0 \mathrm{~mL} / \mathrm{min}$ and the instrument was calibrated using polystyrene standards (Aldrich, 15 standards, 760-1,800,000 Daltons). All flash chromatography was carried out using a 56-mm inner diameter column containing 200-mm of silica gel under a positive pressure of lab air. Absorption spectra were recorded on a Varian Cary 5000 UV-Vis-NIR spectrophotometer using a Starna quartz cell (path length $=10 \mathrm{~mm}$ ). Melting analyses of DNA-modified materials were performed using a HewlettPackard 8453 diode-array spectrophotometer equipped with a HP 89090A Peltier temperature controller.

Materials. Deuterated solvents were purchased from Cambridge Isotope Laboratories and used without further purification, except for $\mathrm{CDCl}_{3}$, which was distilled over calcium hydride and vacuum transferred into an air-tight solvent bulb followed by transfer to an inert-atmosphere glovebox. Amide-linked norbornene-modified indomethacin monomer $(\mathbf{1})^{2}$ and $\alpha$-bromo- $\alpha^{\prime}$-(exo-5-norbornene-2-ol)-p-xylene $(\mathbf{3})^{3}$ were synthesized as described previously. All other reagents were purchased from Aldrich and used without further purification unless otherwise noted.

The random 5'-amine-modified oligonucleotide sequence (22-mer) was synthesized with an Expedite 8909 Nucleic Acid system using standard reagents and a 5'-Amino-Modifier $\mathrm{C}_{6}$ phosphoramidite (Glen Research, Sterling, VA), and dabcyl-functionalized controlled porosity glass (CPG) solid supports (Glen Research). DNA was purified on an Agilent 1100 HPLC equipped with a Varian Dynamax column (250 mm x $10.0 \mathrm{~mm}$ (L x ID) Microsorb 300-10 C18) using a gradient method of $100 \% 0.03 \mathrm{M}$ TEAA in $\mathrm{H}_{2} \mathrm{O}$ at time 0 to $50 \%$ Acetonitrile (containing 5\% of the 0.03M TEAA Buffer) at 50 minutes with a flow rate of $3 \mathrm{~mL} / \mathrm{min}$. The $\mathrm{Bcl}-2$ antisense oligonucleotide sequence complementary to the first six codons of the open reading frame of Bcl-2 mRNA $^{4}$ (5'-amine- $\mathrm{A}_{10}$-iFluor-dT-TCT CCC AGC GTG CGC CAT-3') and other oligonucleotide sequences (Integrated DNA Technologies, Coralville, IA) were used as received. Chicken polyclonal antibody against ErbB2 (ab14027) (anti-HER-2 IgY) and goat polyclonal antibody against chicken IgY (H\&L) (ab6961) (anti-chicken IgY) (Abcam, Cambridge, MA) were used as received. DNA- ${ }^{5}$ and antibody ${ }^{6}$-functionalized GNP probes were prepared according to literature procedures.

\footnotetext{
* Author to whom correspondence should be addressed. Email: stn@ northwestern.edu

${ }^{1}$ Pangborn, A. B.; Giardello, M. A.; Grubbs, R. H.; Rosen, R. K.; Timmers, F. J. Organometallics 1996, 15, 1518-1520.

${ }^{2}$ Bertin, P. A.; Watson, K. J.; Nguyen, S. T. Macromolecules 2004, 37, 8364-8372.

${ }^{3}$ Watson, K. J.; Nguyen, S. T.; Mirkin, C. A. J. Organomet. Chem. 2000, 606, 79-83.

${ }^{4}$ Lopes de Menezes, D. E.; Hudon, N.; McIntosh, N.; Mayer, L. D. Clin. Cancer Res. 2000, 6, 2891-2902.

${ }^{5}$ Storhoff, J. J.; Elghanian, R.; Mucic, R. C.; Mirkin, C. A.; Letsinger, R. L. J. Am. Chem. Soc. 1998, 120, 1959-1964.

${ }^{6}$ Nam, J.- M.; Thaxton, C. S.; Mirkin, C. A. Science 2003, 301, 1884-1886.
} 
Transmission Electron Microscopy. Transmission electron microscopy (TEM) was performed on a Hitachi H8100 microscope operating at an accelerating voltage of $200 \mathrm{kV}$. For the observation of the size and distribution of the copolymer nanoparticles, samples $(5 \mu \mathrm{L})$ were deposited from aqueous solutions of the copolymer nanoparticles onto copper EM grids (Ted Pella, Inc., Redding, CA, 400 mesh, Formvar/carbon-coated). Water was allowed to evaporate from the grids at atmospheric pressure and room temperature. Negative staining was performed by exposing the grids to a solution of $2 \mathrm{wt} \%$ uranyl acetate $(5 \mu \mathrm{L})$ for $2 \mathrm{~min}$. The grids were tapped dry with a filter paper to remove the excess stain. The samples were air-dried before TEM measurement.

Light-Scattering Measurements. Dynamic light-scattering (DLS) measurements were performed on a Brookhaven Instruments Corp. photon correlation spectrometer (BI-200 SM goniometer) fitted with a Brookhaven Instruments BI9000AT digital correlator and a 300-mW argon ion laser at $514 \mathrm{~nm}$. The scattering angle used was $90^{\circ}$. A refractive indexmatching bath of filtered decalin $(0.2 \mathrm{~m})$ surrounded the scattering cell, and the temperature was fixed at $25^{\circ} \mathrm{C}$. Correlation data were fitted-using the method of cumulants-to the logarithm of the correlation function, yielding the diffusion coefficient, $D$. The hydrodynamic diameters $\left(D_{\mathrm{H}}\right)$ of the nanoparticles were calculated using $D$ and the Stokes-Einstein equation ( $D=k_{\mathrm{B}} T / 3 \pi \eta D_{\mathrm{H}}$, where $k_{\mathrm{B}}$ is the Boltzmann constant, $T$ is the absolute temperature, and $\eta$ is the solvent viscosity). The polydispersity factor of the nanoparticles, represented as $\mu_{2} / \Gamma^{2}$, where $\mu_{2}$ is the second cumulant of the decay function and $\Gamma$ is the average characteristic line width, was calculated by the cumulant method. CONTIN algorithms were used in the Laplace inversion of the autocorrelation functions to confirm particle size distributions. All analyses were performed with the supplied instrument software (BIC Dynamic Light Scattering Software). The data reported represent an average of three separate trials.

Fluorescence Microscopy. Fluorescence images were captured using a Leica DM IRE2 inverted microscope with a Sutter DG-4 xenon light source, a Chroma HQ FITC filter cube (Ex: HQ480/40, Em: HQ535/50, BS: Q505lp), and a Photometrics CoolSNAP HQ camera. All fluorescence images were adjusted for brightness using control images as a standard. Linear intensity maps were obtained using the internal quantification routines in the Leica software.

Confocal images were captured using a Leica TCS SP2 confocal system with a DM IRE2 inverted microscope. Twochannel image stacks were obtained sequentially (to eliminate cross-talk between channels) at $488 \mathrm{~nm}$ (Argon laser) for flourescein and $543 \mathrm{~nm}$ (HeNe laser) for Cy 3. Raw images were imported into Improvision's Volocity 3.5.1 software, thresholded, then analyzed via the program's internal algorithms for the extent of colocalization.

\section{Synthetic and Preparative Procedures:}

Norbornene-conjugated hexaethylene glycol (4). Into a 50-mL Schlenk flask was added hexaethylene glycol (1.75 g, 6.2 mmol). The flask was placed under nitrogen after three freeze-pump-thaw cycles and $\mathrm{CH}_{2} \mathrm{Cl}_{2}(5 \mathrm{~mL})$ was added via cannula. In a separate 50-mL Schlenk flask, $\mathrm{Ag}_{2} \mathrm{O}(2.15 \mathrm{~g}, 9.3 \mathrm{mmol})$ and $\mathrm{KI}(412 \mathrm{mg}, 2.5 \mathrm{mmol})$ were added and placed under nitrogen followed by the addition of $\mathrm{CH}_{2} \mathrm{Cl}_{2}(25 \mathrm{~mL})$. To this flask was added the hexaethylene glycol solution dropwise via cannula over a period of 5 min and the suspension was stirred vigorously at ambient temperature.

Into a third 50-mL Schlenk flask, $3(343 \mathrm{mg}, 6.8 \mathrm{mmol})$ was placed under nitrogen, dissolved in $\mathrm{CH}_{2} \mathrm{Cl}_{2}(10 \mathrm{~mL})$, and transferred via cannula to a pressure-equalizing additional funnel fitted above the stirring suspension of hexaethylene glycol. The solution of $\mathbf{3}$ was added dropwise over a period of $10 \mathrm{~min}$ and the reaction mixture was allowed to stir for $2 \mathrm{~h}$ at ambient temperature. The salts were removed by filtration through a pad of Celite 545 which was then washed thoroughly with $\mathrm{CH}_{2} \mathrm{Cl}_{2}$. The combined filtrate was concentrated on a rotary evaporator and the crude residue was purified by column chromatography $\left(10 \% \mathrm{MeOH}: \mathrm{CH}_{2} \mathrm{Cl}_{2}\right)$ to give a colorless oil $(2.08 \mathrm{~g}, 4.2 \mathrm{mmol}, 68 \%)$. ${ }^{1} \mathrm{H} \mathrm{NMR}\left(\mathrm{CDCl}_{3}\right): \delta$ 1.42-1.76 (m, 4H, 3- and 7-norbornenyl- $\left.H_{2}\right), 2.05$ (bs, 1H, -OH), 2.82 (b, 1H, 1-norbornenyl- $H$ ), $2.94(\mathrm{~b}, 1 \mathrm{H}, 4-$ norbornenyl- $\mathrm{H}), 3.59-3.74\left(\mathrm{~m}, 24 \mathrm{H}, \mathrm{OCH}_{2} \mathrm{CH}_{2} \mathrm{O}\right), 4.49-4.56\left(\mathrm{~m}, 5 \mathrm{H}, \mathrm{CH}_{2}-\mathrm{C}_{6} \mathrm{H}_{4}-\mathrm{CH}_{2}\right.$ and 2-norbornenyl- $\left.\mathrm{H}\right), 5.91(\mathrm{~m}, 1 \mathrm{H}$, 6-norbornenyl- $H$ ), 6.19 (m, $1 \mathrm{H}, 5$-norbornenyl- $H$ ), 7.32 (b, 4H, aromatic- $H) .{ }^{13} \mathrm{C}\left\{{ }^{1} \mathrm{H}\right\} \mathrm{NMR}\left(\mathrm{CDCl}_{3}\right): \delta 34.7(3-$ norbornenyl- $C$ ), 40.6 (4-norbornenyl- $C$ ), 46.2 (7-norbornenyl- $C$ ), 46.7 (1-norbornenyl- $C$ ), $62.0\left(\mathrm{CH}_{2} \mathrm{OH}\right), 69.5-71.1$ (m, $\mathrm{OCH}_{2} \mathrm{CH}_{2} \mathrm{O}$ ), 72.8 ( $\mathrm{CH}-\mathrm{O}-\mathrm{CH}_{2}-\mathrm{Ph}$ ), 73.2 ( $\mathrm{Ph}-\mathrm{O}-\mathrm{CH}_{2}-\mathrm{CH}_{2}$ ), 80.2 (2-norbornenyl-C), 127.8 (aromatic-C), 128.0 (aromatic$C$ ), 133.4 (6-norbornenyl- $C$ ), 137.6 (aromatic-C), 138.5 (aromatic- $C$ ), 140.9 (5-norbornenyl- $C$ ). HRMS (APCI): $\mathrm{m} / z$ calcd. For $\mathrm{C}_{27} \mathrm{H}_{43} \mathrm{O}_{8}(\mathrm{M}+\mathrm{H})^{+}$: 495.2952. Found: 495.2947 .

Tosylated norbornene-modified hexaethylene glycol (2) (Scheme S1). To a 50-mL Schlenk flask containing 4 (100 mg, $0.2 \mathrm{mmol})$ under nitrogen was added $\mathrm{CH}_{2} \mathrm{Cl}_{2}(10 \mathrm{~mL})$ via cannula. This solution was set to stir and $\mathrm{Ag}_{2} \mathrm{O}(93.7 \mathrm{mg}, 0.4$ $\mathrm{mmol}), \mathrm{KI}(67.1 \mathrm{mg}, 0.4 \mathrm{mmol})$, and $p$-toluenesulfonyl chloride $(77 \mathrm{mg}, 0.4 \mathrm{mmol})$ were added sequentially as solids under a positive pressure of nitrogen. A condenser was then attached to the flask and the suspension was heated to $40{ }^{\circ} \mathrm{C}$ and allowed to stir for $1 \mathrm{~h}$. Upon cooling to room temperature, the precipitated salts were removed by filtration through a pad of Celite 545, which was then washed with excess $\mathrm{CH}_{2} \mathrm{Cl}_{2}$. The combined filtrate was concentrated on a rotary evaporator and the crude residue was purified by column chromatography ( $5 \% \mathrm{MeOH}: \mathrm{CH}_{2} \mathrm{Cl}_{2}$ ) to yield a colorless oil $(99 \mathrm{mg}, 0.015$ mmol, 75\%). ${ }^{1} \mathrm{H} \mathrm{NMR}\left(\mathrm{CDCl}_{3}\right): \delta 1.42-1.76\left(\mathrm{~m}, 4 \mathrm{H}, 3\right.$ - and 7-norbornenyl- $\left.\mathrm{H}_{2}\right), 2.45\left(\mathrm{~s}, 3 \mathrm{H}\right.$, aromatic- $\left.\mathrm{CH}_{3}\right), 2.82(\mathrm{~b}, 1 \mathrm{H}$, 
1-norbornenyl- $H$ ), 2.94 (b, 1H, 4-norbornenyl- $H$ ), 3.59-3.70 (m, 22H, OCH $\left.\mathrm{CH}_{2} \mathrm{O}\right), 4.16(\mathrm{t}, 2 \mathrm{H}, J=5.0 \mathrm{~Hz}$, $\left.\mathrm{CH}_{2} \mathrm{CH}_{2} \mathrm{OSO}_{2}\right), 4.45-4.56\left(\mathrm{~m}, 5 \mathrm{H}, \mathrm{CH}_{2}-\mathrm{C}_{6} \mathrm{H}_{4}-\mathrm{CH}_{2}\right.$ and 2-norbornenyl- $\left.\mathrm{H}\right), 5.92(\mathrm{~m}, 1 \mathrm{H}, 6$-norbornenyl- $\mathrm{H}), 6.20(\mathrm{~m}, 1 \mathrm{H}, 5-$ norbornenyl- $H$ ), $7.32(\mathrm{~b}, 4 \mathrm{H}$, aromatic- $H), 7.35(\mathrm{~d}, 2 \mathrm{H}, J=8.0 \mathrm{~Hz}$, aromatic- $H), 7.81(\mathrm{~d}, 2 \mathrm{H}, J=8.0 \mathrm{~Hz}$, aromatic- $H)$. ${ }^{13} \mathrm{C}\left\{{ }^{1} \mathrm{H}\right\}$ NMR $\left(\mathrm{CDCl}_{3}\right): \delta 21.9,34.7,40.6,46.2,46.7,68.9,69.4,69.5,70.7-70.9(\mathrm{~m}), 71.1,73.2,80.2,127.8,128.0$, 128.2, 130.0, 133.2, 133.4, 137.6, 138.5, 140.9, 145.0. HRMS (EI): calcd. for $\mathrm{C}_{34} \mathrm{H}_{48} \mathrm{O}_{10} \mathrm{~S}: 648.2963$ Found: 648.2956.

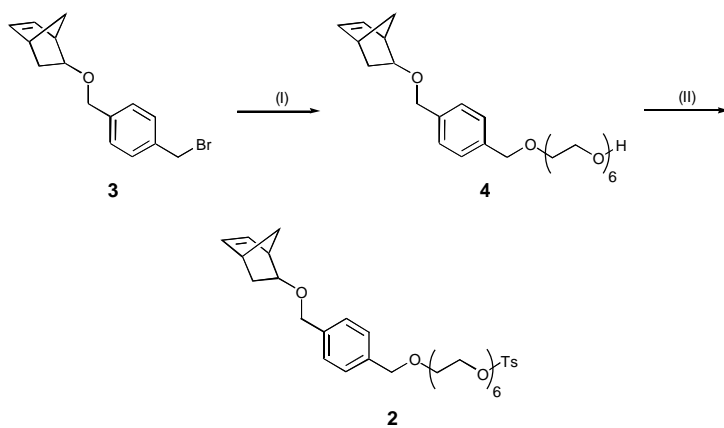

Scheme S1. Synthesis of monomer 2: (i) hexaethylene glycol, $\mathrm{Ag}_{2} \mathrm{O}, \mathrm{KI}, \mathrm{CH}_{2} \mathrm{Cl}_{2}, 68 \%$; (ii) $\mathrm{TsCl}$, $\mathrm{Ag}_{2} \mathrm{O}, \mathrm{KI}, \mathrm{CH}_{2} \mathrm{Cl}_{2}, 75 \%$.
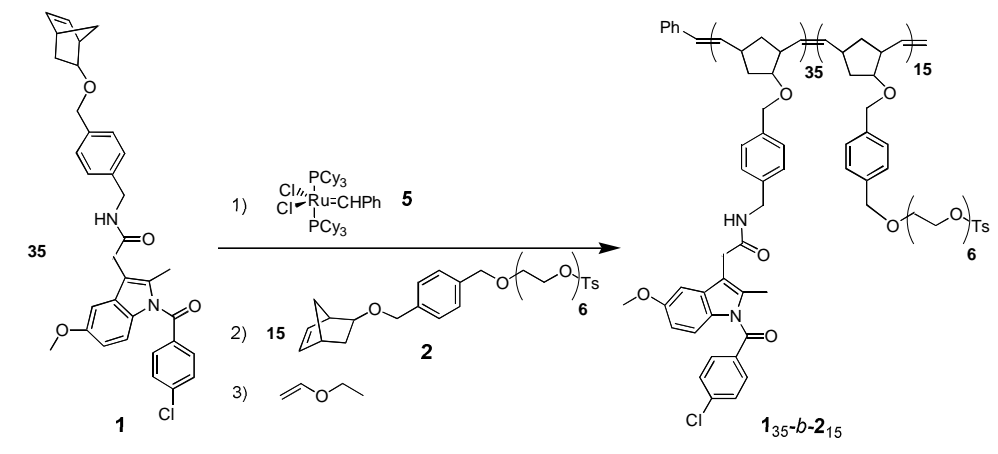

Scheme S2. Synthesis of block copolymer $\mathbf{1}_{35}-b-\mathbf{2}_{15}$.

Preparation of copolymer $\mathbf{1}_{35}-\boldsymbol{b}-\mathbf{2}_{15}$ (Scheme S2). In an inert-atmosphere glovebox, monomer $\mathbf{1}$ (65 mg, $0.11 \mathrm{mmol}$ ) was

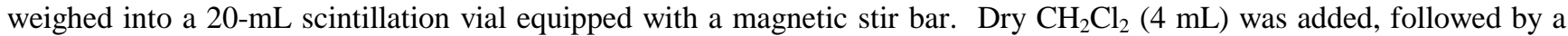
solution of $\mathrm{Cl}_{2}\left(\mathrm{PCy}_{3}\right)_{2} \mathrm{Ru}=\mathrm{CHPh}$ catalyst (Aldrich, Milwaukee, WI) $(2.7 \mathrm{mg}, 0.0033 \mathrm{mmol})$ in $\mathrm{CH}_{2} \mathrm{Cl}_{2}(1 \mathrm{~mL})$. The solution was stirred for $30 \mathrm{~min}$. at room temperature. An aliquot $(100 \mu \mathrm{L})$ was removed, quenched with ethyl vinyl ether $(100 \mu \mathrm{L})$, and analyzed by GPC $\left(M_{\mathrm{n}}=23900, M_{\mathrm{w}} / M_{\mathrm{n}}=1.13\right)$. Subsequently, a solution of monomer $2(31.1 \mathrm{mg}, 0.048$ $\mathrm{mmol})$ in $\mathrm{CH}_{2} \mathrm{Cl}_{2}(1 \mathrm{~mL})$ was added and the solution was allowed to stir for an additional $30 \mathrm{~min}$. The polymerization was terminated with the addition of ethyl vinyl ether $(1 \mathrm{~mL})$. The copolymer $\mathbf{1}_{35}-b-\mathbf{2}_{15}(79 \mathrm{mg}, 83 \%)$ was isolated as an offwhite solid by precipitation into cold pentanes $(200 \mathrm{~mL})$, filtering, and washing with fresh pentanes $(3 \times 50 \mathrm{~mL}) .{ }^{1} \mathrm{H}$ NMR $\left(\mathrm{CDCl}_{3}\right): \delta 1.10-1.44(\mathrm{bm}), 1.57-1.93(\mathrm{bm}), 2.27$ (bs), $2.44(\mathrm{bs}), 2.57-2.68(\mathrm{bm}), 2.92-3.15(\mathrm{bm}), 3.57(\mathrm{bs}), 3.65(\mathrm{bm})$, $3.74(\mathrm{bs}), 4.15(\mathrm{bm}), 4.26-4.54(\mathrm{bm}), 5.20-5.49(\mathrm{bm}), 6.64-7.61(\mathrm{bm}), 7.79(\mathrm{bd})$. GPC: $M_{\mathrm{n}}=30100 ;$ PDI $=1.14$. A transto-cis ratio of 2.8/1 was determined by integrating the peaks of the corresponding olefinic protons of the polynorbornene backbone. On the basis of relative peak integration between the methyl indole protons from monomer $1(\delta=2.27)$ and the methyl protons from the tosyl group in monomer $\mathbf{2}(\delta=2.44)$, the ratio of monomer $\mathbf{1}$ to $\mathbf{2}$ was estimated to be 2.1/1, which is consistent with the reaction stoichiometry of $2.3 / 1$.

Preparation of tosylated polymeric nanoparticles (PNPs). A stock solution of copolymer $\mathbf{1}_{35}-b-\mathbf{2}_{15}(0.01 \mathrm{wt} \%)$ in DMSO was stirred for $4 \mathrm{~h}$ at room temperature to ensure complete polymer solubilization. An aliquot $(8.0 \mathrm{~mL})$ was transferred to a $20-\mathrm{mL}$ scintillation vial and allowed to stir vigorously. Ultrapure water (Millipore, $18.2 \mathrm{M} \Omega \bullet \mathrm{cm}$ resistivity) was added to the stirring copolymer solution at a rate of 1 drop $(40 \mu \mathrm{L}, 0.45 \mathrm{wt} \%)$ per every $10 \mathrm{~s}$ using a micro-pipette until the solution contained $18 \mathrm{wt} \%$ water. The resulting solution was placed in a dialysis tube (Spectrum Laboratories, Rancho Dominguez, CA, Spectra/Por RC, $10-\mathrm{mL}$ Float-a-lyzer, $\mathrm{MWCO}=8000$ ) and dialyzed against ultrapure water in a 500-mL Erlenmeyer flask with the dialysis solution changed every $30 \mathrm{~min}$ for the first 6 hours and then every $8 \mathrm{~h}$ for the next $24 \mathrm{~h}$. Complete removal of DMSO from the filtrate was verified by UV-Vis spectroscopy as indicated by the disappearance of the UV cut-off for DMSO at $268 \mathrm{~nm}$. The nanoparticle suspension $(10.1 \mathrm{~mL})$ was removed from the dialysis membrane and stored in a $20-\mathrm{mL}$ scintillation vial at $10^{\circ} \mathrm{C}$.

General procedure for the preparation of DNA-functionalized PNPs. Tosylated PNP solutions containing 0.01 wt $\%$ copolymer were prepared as stated above. An aliquot $(500 \mu \mathrm{L}, 54 \mu \mathrm{g}$ of copolymer) was transferred to a 1.5 -mL safe lock Eppendorf tube and centrifuged for $30 \mathrm{~min}$ at $10 \mathrm{~K} \mathrm{rpm}$ to a solid pellet. The supernatant was removed and the PNPs were re-suspended in PBS buffer $(250 \mu \mathrm{L}, 10 \mathrm{mM}, \mathrm{pH}=8.5,[\mathrm{NaCl}]=81 \mathrm{mM})$ upon mild vortexing. An aliquot $(100 \mu \mathrm{M})$ of the appropriate 5'-amine-modified oligonucleotide in the same PBS buffer was added and the foil-wrapped suspension was set on a platform shaker $(112 \mathrm{rpm})$ at room temperature for $18 \mathrm{~h}$. Purification of the DNA-modified PNPs was achieved using centrifuge filters (Centricon YM-100, $\mathrm{MWCO}=100,000)$ (Millipore, Billerica, MA) with PBS buffer $(10 \mathrm{mM}, \mathrm{pH}=$ 7.0, $[\mathrm{NaCl}]=0.15 \mathrm{M})$.

To verify DNA functionalization of the PNPs, an aliquot $(10 \mu \mathrm{L})$ of the DNA-modified PNPs was transferred to a separate Eppendorf tube. To this tube was added an aliquot $(1 \mu \mathrm{L}, 10 \mathrm{nM}$ gold $)$ of GNPs $(13 \mathrm{~nm})$ functionalized with the 
complementary DNA sequence in PBS buffer $(10 \mathrm{mM}, \mathrm{pH}=7.0,[\mathrm{NaCl}]=0.15 \mathrm{M})$. The suspension was heated at $65{ }^{\circ} \mathrm{C}$ for $1 \mathrm{~min}$ and allowed to cool to room temperature overnight. Hybridization between the PNPs and the GNPs was confirmed by TEM. Simultaneously, control experiments were carried out between: 1) the tosylated-PNPs and the GNPs $(13 \mathrm{~nm})$ functionalized with the complementary DNA sequence (Figure 1.2) and 2) the DNA-functionalized PNPs and the GNPs $(13 \mathrm{~nm}$ ) functionalized with the non-complementary DNA sequence (Figure S1). Both experiments were performed in the same manner as described above and analyzed by TEM.

The generality of our DNA-conjugation strategy was confirmed upon treatment of our tosylated PNPs with strands of Bcl-2 asODN (28-mer) containing a 5'-terminal amine moiety. Again, hybridization of the resulting Bcl-2 asODNfunctionalized PNPs with complementary 13-nm GNP probes was observed by TEM (Figure S2), while control samples with tosylated PNPs revealed minimal non-specific interaction.

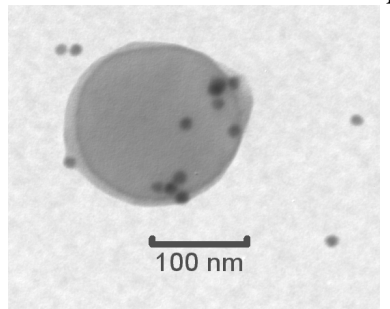

Figure S1. TEM image of random 22-mer DNAfunctionalized PNP combined with 13-nm GNP probes functionalized with non-complementary DNA sequences.

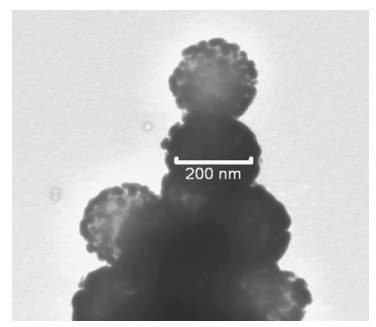

Figure S2. TEM image of PNPs functionalized with Bcl-2 asODNs and hybridized to 13 -nm GNP probes functionalized with the complementary ODN sequences.

Thermal denaturation experiments of hybrids formed between the DNA-functionalized PNPs and GNPs (13 nm) functionalized with the complementary DNA sequence were performed as follows. DNA-functionalized PNPs $(500 \mu \mathrm{L}$, $108 \mu \mathrm{g}$ of copolymer) were combined with $(50 \mu \mathrm{L}, 10 \mathrm{nM}$ gold) of GNPs $(13 \mathrm{~nm})$ functionalized with the complementary DNA sequence in PBS buffer $(10 \mathrm{mM}, \mathrm{pH}=7.0,[\mathrm{NaCl}]=0.15 \mathrm{M})$ and were allowed to hybridize overnight. The sample was diluted with the same PBS buffer (1 mL total volume). The melting transition was monitored at $260 \mathrm{~nm}$ and $520 \mathrm{~nm}$ from $20{ }^{\circ} \mathrm{C}$ to $70{ }^{\circ} \mathrm{C}$ at intervals of $1{ }^{\circ} \mathrm{C}$ with a hold time of 1 min per interval (Figure S3).
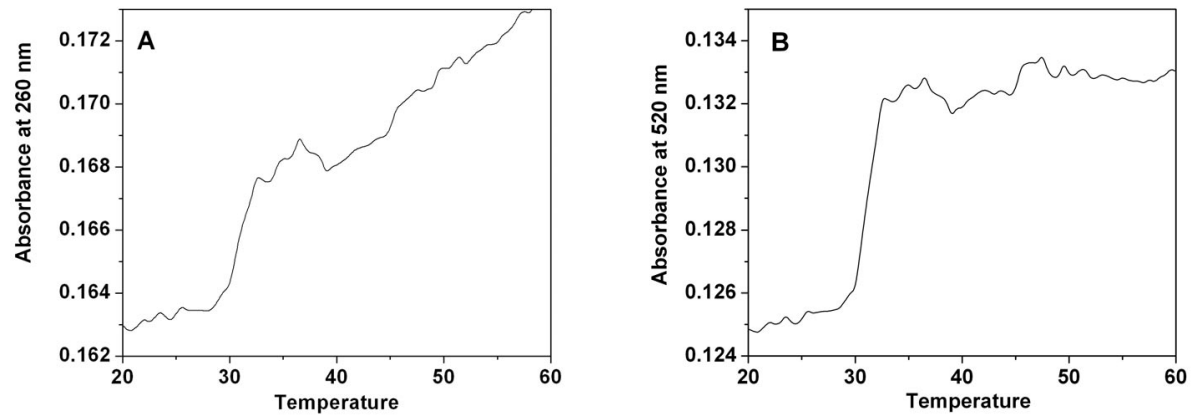

Figure S3. Thermal denaturation curves of DNA-templated PNP-GNP hybrids monitored at (A) $260 \mathrm{~nm}$ and (B) $520 \mathrm{~nm}$.

Preparation of antibody-functionalized PNPs. Tosylated PNP solutions containing $0.01 \mathrm{wt} \%$ copolymer were prepared as stated above. An aliquot $(500 \mu \mathrm{L}, 54 \mu \mathrm{g}$ of copolymer) was transferred to a 1.5 -mL safe lock Eppendorf tube and centrifuged for $30 \mathrm{~min}$ at $10 \mathrm{~K} \mathrm{rpm}$ to yield a solid pellet. The supernatant was removed and the PNPs were re-suspended in PBS buffer $(250 \mu \mathrm{L}, 10 \mathrm{mM}, \mathrm{pH}=8.5,[\mathrm{NaCl}]=0.15 \mathrm{M})$ upon mild vortexing. An aliquot $(10 \mu \mathrm{g})$ of chicken anti-HER-2 $\operatorname{IgY}$ (Abcam, Inc., Cambridge, MA) in PBS buffer $(10 \mathrm{mM}, \mathrm{pH}=7.0,[\mathrm{NaCl}]=0.15 \mathrm{M})$ was added and the suspension incubated in a thermomixer at $4{ }^{\circ} \mathrm{C}$ and $1150 \mathrm{rpm}$ for $72 \mathrm{~h}$. The Eppendorf tube was centrifuged at $4{ }^{\circ} \mathrm{C}$ for $30 \mathrm{~min}$ at $10 \mathrm{~K}$ rpm leaving a barely visible pellet. The supernatant was removed and the pAb-modified PNPs were resuspended in PBS buffer $(50 \mu \mathrm{L}, 10 \mathrm{mM}, \mathrm{pH}=7.0,[\mathrm{NaCl}]=0.15 \mathrm{M})$ upon mild vortexing.

To verify pAb functionalization of the PNPs, an aliquot $(20 \mu \mathrm{L}, 10 \mathrm{nM}$ gold) of GNPs $(30 \mathrm{~nm})$ functionalized with goat pAbs against chicken IgY (Abcam, Inc., Cambridge, MA) in PBS buffer $(10 \mathrm{mM}, \mathrm{pH}=7.0,[\mathrm{NaCl}]=0.15 \mathrm{M})$ was added to the pAb-modified PNPs $(50 \mu \mathrm{L})$. The suspension was set to incubate at room temperature on a platform shaker at 112 rpm overnight. Simultaneously, a control experiment was carried out between the tosylated-PNPs and the GNPs (30 $\mathrm{nm}$ ) functionalized with secondary abs to the chicken $\operatorname{IgY}$ in the same manner. 
Preparation of DNA- and antibody-functionalized PNPs. Tosylated PNP solutions containing 0.01 wt $\%$ copolymer were prepared as stated above. An aliquot $(200 \mu \mathrm{L}, 22 \mu \mathrm{g}$ of copolymer) was transferred to a 1.5 -mL safe lock Eppendorf tube and centrifuged for $30 \mathrm{~min}$ at $10 \mathrm{~K} \mathrm{rpm}$ to yield a solid pellet. The supernatant was removed and the PNPs were resuspended in PBS buffer $(100 \mu \mathrm{L}, 10 \mathrm{mM}, \mathrm{pH}=8.5,[\mathrm{NaCl}]=0.15 \mathrm{M})$ upon mild vortexing. An aliquot $(5 \mu \mathrm{g})$ of chicken $\mathrm{pAb}$ to ErbB2 in PBS buffer $(10 \mathrm{mM}, \mathrm{pH}=7.0,[\mathrm{NaCl}]=0.15 \mathrm{M})$ was added and the suspension agitated on a platform shaker (200 rpm) for $2 \mathrm{~h}$. To the suspension was added the 5'-amine-modified Bcl2 antisense oligonucleotide sequence $(100 \mu \mathrm{M})$ in the same PBS buffer and agitation was continued on a platform shaker $(200 \mathrm{rpm})$ for an additional $18 \mathrm{~h}$. The functionalized PNPs were purified by repeated $(2 \mathrm{x})$ centrifugation $(30 \mathrm{~min}$ at $10 \mathrm{~K} \mathrm{rpm})$ to a solid pellet, removal of the supernatant, and re-suspension in PBS buffer $(100 \mu \mathrm{L}, 10 \mathrm{mM}, \mathrm{pH}=7.0,[\mathrm{NaCl}]=0.15 \mathrm{M})$ with mild vortexing.

To verify combined pAb- and DNA-functionalization of the PNPs, an aliquot $(8 \mu \mathrm{L})$ of the modified PNPs was transferred to a separate Eppendorf tube. To this tube was then added an aliquot $(1 \mu \mathrm{L}, 10 \mathrm{nM}$ gold $)$ of GNP (13 nm) probes functionalized with an oligonucleotide sequence that is complementary to the Bcl2 sequence in PBS buffer $(10 \mathrm{mM}, \mathrm{pH}=$ $7.0,[\mathrm{NaCl}]=0.15 \mathrm{M})$. Additionally, an aliquot $(1 \mu \mathrm{L}, 10 \mathrm{nM}$ gold $)$ of GNP $(30 \mathrm{~nm})$ probes functionalized with goat pAbs to chicken IgY was added to the suspension in the same PBS buffer. The sample was wrapped in foil and left at room temperature overnight. We note that this control experiment was carried out at neutral pH in contrast to the antibodyimmobilization (vide supra) where the $\mathrm{pH}$ was kept at a more basic level to encourage surface bio-conjugation.

Cell Culture and PNP internalization. The human breast carcinoma cell line SKBR3 (ATCC, Rockville, MD) was cultured in modified McCoy's 5A medium (ATTC) supplemented with 10\% (v/v) FBS (Harlan, Indianapolis, IN), 1\% (v/v) penicillin $(10000 \mathrm{U} / \mathrm{mL}), 1 \%(\mathrm{v} / \mathrm{v})$ streptomycin $(10 \mathrm{mg} / \mathrm{mL})$, tetracycline antibiotic $(1 \mu \mathrm{g} / \mathrm{mL})$. Cells were passaged at subconfluence by trypsinization ( $0.05 \%$ trypsin, $0.02 \%$ EDTA), incubated at $37{ }^{\circ} \mathrm{C}, 90 \%$ humidity, and $5 \% \mathrm{CO}_{2}$, and seeded at $c a 10,000$ cells $/ \mathrm{cm}^{2}$ on top of sterilized glass cover slides in a 6-well plate (Becton Dickinson) in cell media for one week.

PNPs ( $100 \mu \mathrm{L}$ in PBS, $2 \mu \mathrm{g} / \mathrm{mL})$ were applied to each well $16 \mathrm{~h}$ before imaging. The glass slide was then taken out and rinsed with PBS buffer $(3 \times 1 \mathrm{~mL})$. The cells were fixed by exposure to a solution of $2 \%$ formaldehyde in PBS (Electron Microscopy Science, diluted to 50\%) for $15 \mathrm{~min}$ at room temperature. The slide was then rinsed three times with PBS buffer (3 x $1 \mathrm{~mL}$ ), coated with BacLight mounting oil (Invitrogen, Carlsbad, CA) and imaged using a Leica DM IRE2 fluorescence microscope.

For samples in which secondary antibody was used to label PNP intracellular distribution, cells were permeabilized with $0.1 \%$ Triton X-100 (Sigma, St. Louis, MO) for $3 \mathrm{~min}$ and rinsed twice with PBS after PNP incubation. Then, samples were blocked with 2\% BSA (Sigma) in PBS for 1 hour and incubated with diluted goat polyclonal Cy3-labeled anti-chicken $\operatorname{IgY}(1: 100$, Abcam) solution in a humidified chamber at room temperature for $45 \mathrm{~min}$. After being washed with PBS three times, samples were coated with BacLight mounting oil (Invitrogen) and imaged with a Leica DM IRE2 confocal laserscanning fluorescence microscope.

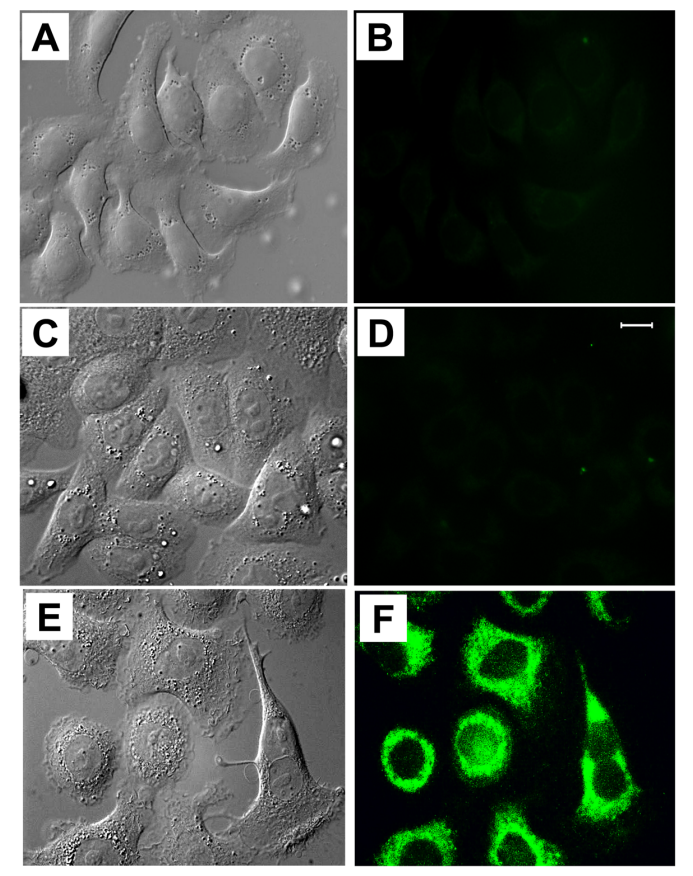

Figure S4. (A) DIC and (B) fluorescence microscopy images of SKBR3 cells after incubation with fluorescein-dTlabeled Bcl-2 asODN-functionalized PNPs for $16 \mathrm{~h}$. (C) DIC and (D) fluorescence microscopy images of 
SKBR3 cells after incubation with single stranded fluorescein-dT-labeled Bcl-2 asODN. (E) DIC and (F) fluorescence microscopy images SKBR3 cells incubated with PNPs functionalized with both fluorescein-dTlabeled Bcl-2 asODNs and anti-HER-2 IgYs. A side-by-side comparison between panels B, D, and F clearly show that significant fluorescence is only observed in panel $\mathrm{F}$. The scale is the same for all images (bar $=10$ $\mu \mathrm{m})$. DIC $=$ Differential interference contrast. 